\title{
SIMULASI PENETAPAN KARAKTERISTIK PENGERINGAN SEMPROT LATEKS BERDASARKAN TEKNIK KOMPUTASI DINAMIKA FLUIDA
}

\author{
Simulation of Spray Drying Characteristic Determination of Latex Based on \\ Computational Fluid Dynamic Technique
}

\author{
Afrizal VACHLEPI ${ }^{1}$, Didin SUWARDIN ${ }^{1}$ dan A. Zainal ABIDIN ${ }^{2}$
}

${ }^{1}$ Balai Penelitian Sembawa, Pusat Penelitian Karet

Jl. Raya Palembang-P.Balai Km.29 PO Box 1127 Palembang 30001

Email : a_vachlepi@yahoo.com, didin.suwardin@yahoo.com

${ }^{2}$ Departemen Teknik Kimia

Fakultas Teknologi Industri - Institut Teknologi Bandung

Jl. Ganesha No. 10 Bandung, Jawa Barat 40132

Email : zainal@che.itb.ac.id

Diterima tanggal 1 November 2012 / Disetujui tanggal 7 April 2013

\begin{abstract}
The purpose of this research was to study the characteristics of natural rubber latex drying process with a unit spray dryer using computational fluid dynamic (CFD) technique approach. The research activities included the determination of CFD model to describe the spray drying system, boundary condition of simulation, operation parameters, and drying simulation. The treatment variations of latex water contents were 65\%, 70\%, 75\%, and 80\%. While the variations of drying air temperatures consisted of $140^{\circ} \mathrm{C}, 150^{\circ} \mathrm{C}, 160^{\circ} \mathrm{C}, 170^{\circ} \mathrm{C}$, and $180^{\circ} \mathrm{C}$. The research concluded that latex water content and drying air temperature affected the drying process depending on airparticle velocity, drying time, particle diameter, product water content, and temperature changes in the air-particles. CFD simulations predicted that the particle diameter of final product was around 130135 micrometer with water contents of 0.32 $0.58 \%$. Temperatures of final product left drying chamber were around $37-54^{\circ} \mathrm{C}$.
\end{abstract}

Keywords : Latex, simulation, spray drying

\begin{abstract}
Abstrak
Tujuan dari penelitian ini adalah untuk mempelajari karakteristik proses pengeringan lateks karet alam dengan alat pengering semprot menggunakan pendekatan teknik komputasi dinamika fluida (computational fluid dynamic/CFD). Kegiatan penelitian ini meliputi penentuan model CFD untuk menggambarkan sistem pengeringan semprot, penentuan kondisi batas simulasi, penentuan parameter operasi, dan simulasi pengeringan. Variasi perlakuan berupa kadar air lateks terdiri atas $65 \%, 70 \%, 75 \%$, dan $80 \%$, sedangkan suhu udara pengering terdiri atas $140^{\circ} \mathrm{C}$, $150^{\circ} \mathrm{C}, 160^{\circ} \mathrm{C}, 170^{\circ} \mathrm{C}$, dan $180^{\circ} \mathrm{C}$. Hasil penelitian menunjukkan bahwa kadar air lateks dan suhu udara pengering berpengaruh terhadap proses pengeringan yang dipengaruhi oleh kecepatan udara-partikel, waktu pengeringan, diameter partikel, kadar air produk, dan perubahan suhu udarapartikel. Simulasi CFD memprediksi diameter partikel produk akhir sekitar 130 135 mikrometer dengan kadar air sekitar 0,32 - 0,58\%. Suhu produk akhir yang keluar dari ruang pengering adalah sekitar $37-54^{\circ} \mathrm{C}$.
\end{abstract}

Kata kunci: Lateks, simulasi, pengeringan semprot 


\section{PENDAHULUAN}

Indonesia merupakan negara penghasil karet terbesar kedua di dunia dengan total produksi tahun 2011 sebesar 3,09 juta ton (Dirjenbun, 2011). Sayangnya kualitas ekspor karet Indonesia masih belum baik dibandingkan dengan negara produsen karet lainnya seperti Thailand, Malaysia, dan Vietnam. Selain itu, proses pengolahan karet alam di Indonesia juga masih kurang efisien karena harus melewati tahapan proses yang panjang dan memerlukan waktu yang lama, seperti pada pengolahan karet remah dan karet sit. Sebelum dikeringkan kedua produk karet padat ini terlebih dahulu harus melalui proses penggumpalan, penggilingan, dan penggantungan.

Meskipun relatif lebih singkat, pengolahan lateks pekat juga dinilai masih belum efisien. Lateks pekat masih mengandung air dan amonia sebagai anti koagulan yang berpengaruh terutama pada proses pengangkutan dan penyimpanan. Beberapa pengaruh air yang terdapat pada lateks pekat antara lain meningkatkan biaya transportasi karena sebagian biaya digunakan untuk mengangkut air, penggunaan kemasan yang besar, dan memerlukan penanganan yang lebih ketat karena adanya amonia.

Untuk mengatasi permasalahan tersebut dapat dilakukan dengan mengolah lateks menjadi produk serbuk atau tepung lateks (latex powder). Selain efisien dalam pengangkutan, Zbicinski dan Zietara (2004) menyatakan bahwa pengurangan atau penurunan kandungan dan aktivitas air mempunyai pengaruh positif terhadap kualitas produk. Tepung yang kering cenderung mudah dikemas dengan kualitas terjaga. Teknologi yang dapat digunakan untuk menghasilkan tepung lateks adalah pengeringan semprot (spray drying). Untuk itu, perlu dirancang alat pengering semprot yang khusus digunakan untuk mengeringkan lateks karet alam. Abidin dan Vachlepi (2011) telah merancang alat pengering semprot untuk lateks dengan kapasitas olah sekitar 200 liter per jam.
Dalam sistem pengering semprot, parameter yang penting adalah dimensi ruang pengering, laju alir udara pengering dan waktu tinggal partikel di dalam alat pengering semprot. Rancangan ruang pengering dari alat pengering semprot tergantung pada keinginan karakteristik produk akhir. Spesifikasi paling umum produk berkenaan dengan ukuran partikel akhir dan jumlah pelarut pada produk akhir.

Simulasi merupakan suatu usaha untuk mendapatkan gambaran dari kelakuan nyata sebuah sistem dalam hal ini pengeringan semprot. Teknologi pengeringan semprot sudah lama digunakan dalam industri, tetapi masih sangat sulit untuk memodelkan penampilan (performance) peralatan pengeringan semprot. Beberapa studi sudah dilakukan untuk memodelkan proses yang terjadi di dalam teknologi pengeringan semprot. Selama pengeringan, perpindahan massa dan panas terjadi diantara udara dan partikel, yang diakibatkan oleh penurunan suhu udara dan peningkatan kelembaban.

Penerapan teknik komputasi dinamika fluida (computational fluid dynamic/CFD) dalam analisis pengeringan semprot telah dilakukan dan dilaporkan. Dalam pendekatan CFD campuran udara dan lateks ditunjukkan oleh kombinasi aliran udara dan lintasan partikel, suhu yang dihasilkan dan kelembaban udara di dalam ruang pengering. Dari beberapa penelitian yang sudah dilakukan kebanyakan difokuskan hanya pada satu aspek, seperti aliran udara atau suhu dan kelembapan (Kievert, 1997). Dengan perkembangan CFD sekarang, penelitian yang lebih terintegrasi mungkin dikerjakan dengan mempertimbangkan beberapa aspek.

Tujuan dari penelitian ini adalah untuk mempelajari karakteristik proses pengeringan lateks karet alam dengan alat pengering semprot menggunakan pendekatan teknik komputasi dinamika fluida. Karakteristik proses pengeringan dipelajari berdasarkan pengaruh kadar air lateks dan suhu udara pengering selama simulasi dilakukan. 


\section{BAHAN DAN METODE}

Penelitian ini dilaksanakan di Laboratorium Teknologi Polimer dan Membran Program Studi Teknik Kimia, Institut Teknologi Bandung dan Laboratorium Teknologi Pengolahan, Balai Penelitian Sembawa dari bulan Oktober 2011 sampai Januari 2012. Bahan yang digunakan adalah lateks segar dari kebun percobaan Balai Penelitian Sembawa. Lateks ini digunakan untuk pengambilan data karakteristik umpan lateks yang akan digunakan dalam simulasi matematik.

Tahapan kegiatan yang dilakukan dalam penelitian ini yaitu penentuan variasi perlakuan, penentuan parameter operasi dan simulasi proses pengeringan. Variasi perlakuan terdiri atas dua yaitu kadar air lateks dan suhu udara pengering. Pertama, kadar air lateks terdiri atas $65 \%, 70 \%, 75 \%$, dan $80 \%$. Kedua, perlakuan suhu udara pengering terdiri atas $140^{\circ} \mathrm{C}, 150^{\circ} \mathrm{C}, 160^{\circ} \mathrm{C}$, $170^{\circ} \mathrm{C}$, dan $180^{\circ} \mathrm{C}$. Pengamatan untuk proses pengeringan lateks terdiri atas kecepatan tetesan lateks, kecepatan udara pengering, kadar air tetesan/partikel lateks, diameter partikel, waktu lintasan partikel di dalam ruang pengering, perubahan suhu partikel dan udara pengering.

\section{Simulasi Proses Pengeringan Lateks Karet Alam}

Diagram alir prosedur simulasi proses pengeringan lateks karet alam disajikan Gambar 1.

\section{Penentuan CFD Model untuk Pengeringan Semprot}

Sebuah fenomena penyemprotan biasanya digambarkan dengan sejumlah partikel diskret yang disebut dengan model tetesan diskret (Kievert, 1997). Model ini juga dipilih untuk menggambarkan proses penyemprotan lateks ke dalam ruang pengering. Untuk simulasinya diperlukan data-data karakteristik lateks yang diperoleh dari analisis di laboratorium dan studi literatur.

Dalam model ini juga ditentukan jenis penyemprot (sprayer) yang akan digunakan yaitu penyemprot bertekanan (pressure sprayer) dengan sudut penyemprotan $60^{\circ}$. Cairan yang bercampur udara didorong ke arah dinding dan membentuk udara berlubang. Tekanan yang digunakan biasanya berkisar $5-7 \mathrm{MPa}$ (Filkova dan

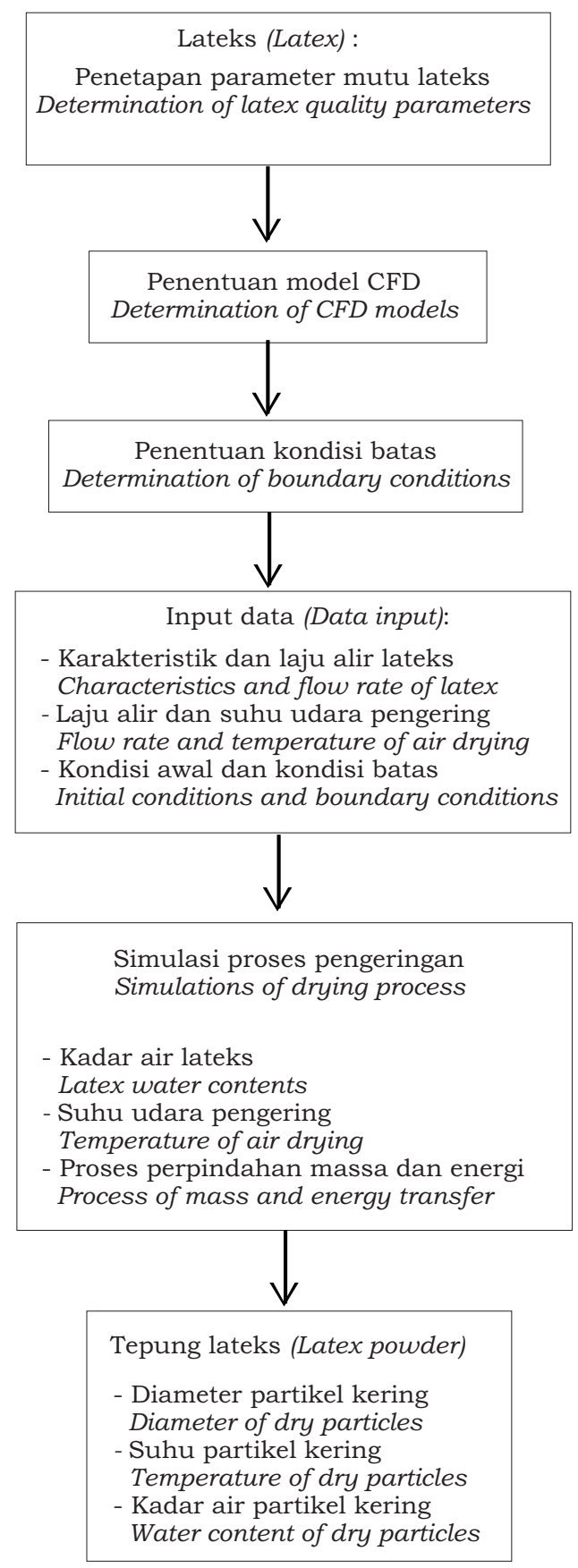

Gambar 1. Diagram alir simulasi pengeringan lateks

Figure 1. Flow chart of latex drying simulation 
Mujumdar, 1995). Energi tekanan yang diberikan ke nosel akan diubah menjadi energi kinetik di lubang nosel. Bagian internal nosel secara normal didesain untuk aplikasi penggunaan sejumlah udara untuk aliran lateks (Genskow et al., 2008). Dengan nosel jenis ini biasanya menghasilkan tetesan dengan ukuran diameter kecil dan partikel kering berbentuk bulat berlubang (poros).

Untuk model aliran turbulen yang terjadi di dalam ruang pengering, digunakan model $\mathrm{k}-\varepsilon$ standar atau disebut juga dengan model dua persamaan. Model ini merupakan model aliran turbulen lengkap yang paling sederhana. Model $\mathrm{k}-\varepsilon$ adalah model yang paling biasa digunakan dalam praktek keteknikan karena memerlukan sedikit data dalam komputasi. Dengan ketahanan (robustness), ekonomi dan kelayakan akurasi untuk cakupan yang luas dari aliran turbulen, menjelaskan model ini paling populer digunakan dalam industri dan simulasi perpindahan panas. Konstanta besaran nilai energi kinetik turbulen (k) dan laju dissipasi turbulen $(\varepsilon)$ untuk sistem pengeringan semprot disajikan pada Tabel 1 .

Selain model penyemprotan dan turbulensi, dalam simulasi ini juga digunakan model perpindahan jenis (species transport) fluida. Model ini diperlukan untuk proses pengeringan yang melibatkan perpindahan massa (pelarut) dan energi dari tetesan lateks ke udara pengering. Karena tidak ada reaksi yang terjadi maka pada model ini hanya difusi panas yang diperlukan. Dalam model ini, ditentukan juga jenis fluida yang terdapat dan akan terbentuk di dalam ruang pengering. Jenis fluida yang dipilih berupa campuran (mixture) yang kandungannya terdiri atas Oksigen $\left(\mathrm{O}_{2}\right)$, Nitrogen $\left(\mathrm{N}_{2}\right)$ dan uap air. Uap air yang terbentuk dan terakumulasi ini sebagian besar berasal dari penguapan air dari tetesan lateks.

\section{Kondisi Batas Simulasi}

Kondisi batas untuk simulasi CFD terdiri atas bentuk geometri dan dimensi ruang pengering, jenis dan ukuran nosel, posisi dari aliran udara pengering-lateks, aliran keluar (produk dan udara buangan) serta laju alir dari udara pengering. Laju alir udara kering dihitung berdasarkan proses pengeringan untuk lateks dengan kadar air $80 \%$ menggunakan udara pengering bersuhu $140^{\circ} \mathrm{C}$ yaitu sekitar $1 \mathrm{~kg} / \mathrm{s}$. Posisi dan bentuk geometri berkaitan dengan kecepatan, pola aliran dan arah fluida. Dengan posisi nosel dan pipa udara di atas, maka aliran dan arah fluida mengarah ke bagian bawah. Ukuran diameter lubang nosel yang digunakan adalah 3,5 $\mathrm{mm}$.

Tabel 1. Data untuk simulasi kinerja pengering semprot

Table 1. Data of simulation performance of spray dryer

\begin{tabular}{lccc}
\multicolumn{1}{c}{$\begin{array}{c}\text { Parameter } \\
\text { Parameters }\end{array}$} & $\begin{array}{c}\text { Satuan } \\
\text { Unit }\end{array}$ & $\begin{array}{c}\text { Nilai } \\
\text { Value }\end{array}$ & $\begin{array}{c}\text { Sumber } \\
\text { Sources }\end{array}$ \\
\hline $\begin{array}{l}\text { Laju alir udara pengering } \\
\text { Drying air flow rate } \\
\text { Laju alir volumetrik lateks } \\
\text { Latex volumetric flow rate } \\
\text { Ketebalan dinding }\end{array}$ & $\mathrm{kg} / \mathrm{s}$ & 1 & - \\
$\begin{array}{l}\text { Wall thickness } \\
\text { Energi kinetik turbulen } \\
\text { Turbulent kinetic energy } \\
\text { Laju dissipasi turbulen } \\
\text { Turbulent dissipation rate }\end{array}$ & $\mathrm{m}^{3} / \mathrm{s}$ & $6 \times 10-5$ & - \\
$\begin{array}{l}\text { Suhu awal lateks } \\
\text { Latex intial temperature }\end{array}$ & $\mathrm{m}$ & 0,002 & Kievert (1997) \\
\hline
\end{tabular}




\section{Simulasi Kinerja}

Data-data yang digunakan sebagai konstanta untuk simulasi ditampilkan pada Tabel 1. Material dari ruang pengering untuk pengeringan lateks ditetapkan terbuat dari aluminium. Oleh karena itu untuk data fisik material ruang pengering yang dimasukkan ke dalam simulasi CFD merupakan data dari aluminium, sedangkan prosedur simulasi proses pengeringan umpan dapat dilihat pada Gambar 1.

Pada kajian penelitian ini, simulasi yang dilakukan adalah simulasi menggunakan teknik CFD. Selama pengeringan, perpindahan massa dan panas terjadi di antara udara dan partikel, dan sebagai akibat penurunan suhu udara dan peningkatan kelembaban. Kedua peristiwa perpindahan tersebut akan diselesaikan secara bersamaan (simultan). Kievert (1997) menyatakan bahwa persamaan dasar aliran fluida adalah persamaan Navier-Stokes (konversi momentum) dan persamaan kontinuitas. Persamaan ini dapat ditemukan di setiap standar kerja pada pemodelan aliran fluida, seperti pada Bird et al. (2002).

Sebuah penyelesaian untuk pola aliran yang dibentuk, dilakukan dengan menghitung perkiraan penyelesaian the Navier-Stoke dan persamaan kontinuitas pada kisi pengendalian volume. Sepanjang lintasan, perpindahan massa, energi, dan momentum dengan perubahan fase terus menerus dihitung. Lintasan partikel (tetesan) dihitung dengan mengintegrasikan persamaan gerak (equations of motion) dari waktu ke waktu. Persamaan ini menyatukan beberapa terminologi seperti gaya gravitasi dan gaya seret oleh udara. Gaya seret tergantung oleh kecepatan udara, dimana tersedia dari penyelesaian aliran udara.

Nilai $\mathrm{P}_{\text {sat }}$ adalah tekanan jenuh $(\mathrm{Pa}) ; \mathrm{A}_{\mathrm{w}}$ adalah aktivitas air; $\mathrm{M}_{\mathrm{w}}$ adalah kadar air $\left(\mathrm{kg} / \mathrm{m}^{3}\right) ; \mathrm{N}_{\text {vap }}$ dan $\mathrm{N}_{\text {udara }}$ adalah berat molekul uap air dan udara $(\mathrm{kg} / \mathrm{kmol}) ; \mathrm{P}_{\text {ambient }}$ adalah tekanan pada kondisi ambient $(\mathrm{Pa}) ; \mathrm{Q}$ adalah fluks panas $\left(\mathrm{J} \cdot \mathrm{m}^{2} / \mathrm{s}\right)$; dan $\Delta \mathrm{H}_{\text {vap }}$ adalah panas penguapan air ke udara $(\mathrm{J} / \mathrm{kg})$. Untuk simbol $\mathrm{k}_{\mathrm{f}}$ menunjukkan konduktivitas panas (J/s.m.K); Nu adalah nilai bilangan Nusselt yang tidak berdimensi, $\mathrm{T}_{\mathrm{g}}$ dan $\mathrm{T}$ adalah suhu pada fase gas dan suhu ambient $(\mathrm{K}) ; \mathrm{R}_{2}$ dan $\mathrm{R}_{\mathrm{s}}$ adalah jari-jari partikel lateks dan ketebalan lapisan kulit partikel (m); $j_{\mathrm{wi}}$ adalah fluks air antar muka partikel $(\mathrm{kg} / \mathrm{m} . \mathrm{s}) ; \mathrm{R}_{1}$ adalah jari-jari gelembung udara $(\mathrm{m})$; $\mathrm{x}$ adalah rasio padatan dan air $(\mathrm{kg}$ air $/ \mathrm{kg}$ padatan); $d_{s}$ dan $d_{w}$ adalah densitas spesifik padatan dan air $\left(\mathrm{kg} / \mathrm{m}^{3}\right)$.

Sementara itu, untuk simbol $\mathrm{r}$ adalah ruang koordinat dalam hal ini diasumsikan bola (m); t adalah waktu (s); $\rho_{\mathrm{w}}$ dan $\rho_{\mathrm{wo}}$ adalah konsentrasi air dan konsentrasi air awal $\left(\mathrm{kg} / \mathrm{m}^{3}\right) ; \mathrm{D}_{\mathrm{w}}$ adalah koefisien difusi air di

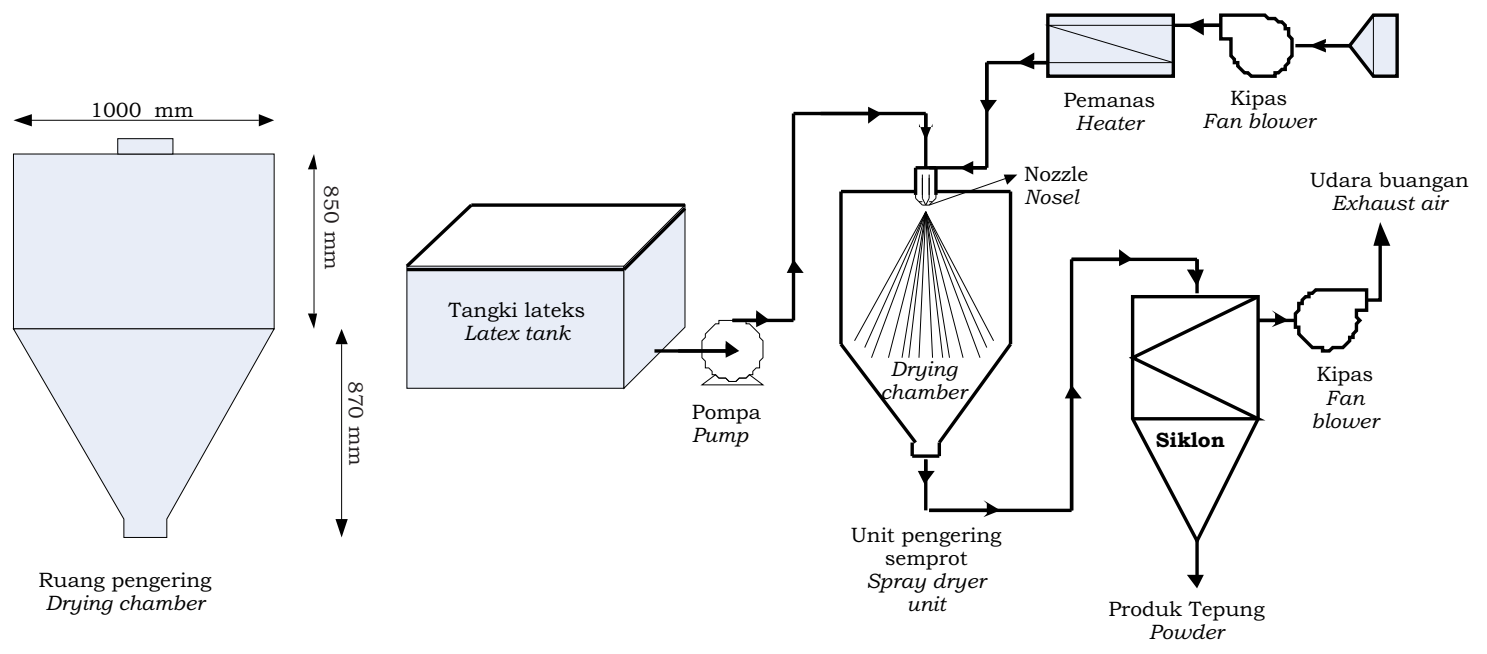

Gambar 2. Ruang pengering dan unit pengering semprot proses pengeringan lateks

Figure 2. Drying chamber and spray dryer unit (for latex drying process) 
Tabel 2. Persamaan matematik untuk proses pengeringan semprot

Table 2. Mathematical equations of spray drying process.

\begin{tabular}{|c|c|c|c|}
\hline No. & $\begin{array}{l}\text { Pengamatan } \\
\text { Observations }\end{array}$ & $\begin{array}{l}\text { Persamaan } \\
\text { Equations }\end{array}$ & $\begin{array}{l}\text { Referensi } \\
\text { References }\end{array}$ \\
\hline 1 & $\begin{array}{l}\text { Perpindahan massa } \\
\text { Mass transfer }\end{array}$ & $\frac{d m}{d t}=\pi$. D. Sh. $D_{\text {diff }} P_{g} \operatorname{In} \frac{1-\omega_{i}}{1-\omega_{g}}$ & $\begin{array}{l}\text { Kievert } \\
(1997)\end{array}$ \\
\hline 2 & $\begin{array}{l}\text { Tekanan uap } \\
\text { Vapor pressure }\end{array}$ & $P_{\text {vap }}=P_{\text {sat }}(T) \cdot A_{w}\left(M_{w}\right)$ & $\begin{array}{l}\text { Kievert } \\
(1997)\end{array}$ \\
\hline 3 & $\begin{array}{l}\text { Fraksi massa uap } \\
\text { Vapor mass fraction }\end{array}$ & $\omega_{i}=\frac{P_{\text {vap }, i} \cdot N_{\text {vap }}}{P_{\text {vap }, i .}\left(N_{\text {vap }}-N_{\text {udara }}\right)+P_{\text {ambient }} \cdot N_{\text {udara }}}$ & $\begin{array}{l}\text { Kievert } \\
(1997)\end{array}$ \\
\hline 4 & $\begin{array}{l}\text { Laju penguapan } \\
\text { Evaporation rate }\end{array}$ & $\frac{d m}{d t}=-\frac{Q}{\Delta H v a p}$ & $\begin{array}{l}\text { Kievert } \\
(1997)\end{array}$ \\
\hline 5 & $\begin{array}{l}\text { Laju penguapan di } \\
\text { atas titik didih } \\
\text { Evaporation rate } \\
\text { above boiling point }\end{array}$ & $\frac{d m}{d t}=-\frac{\pi \cdot D \cdot K_{f} \cdot N_{u}\left(T_{g}-T\right)}{\Delta H v a p}$ & $\begin{array}{l}\text { Kievert } \\
(1997)\end{array}$ \\
\hline 6 & $\begin{array}{l}\text { Laju penguapan dengan } \\
\text { fluks massa } \\
\text { Evaporation rate with } \\
\text { mass flux }\end{array}$ & $\frac{d m}{d t}=-4 \pi \cdot R_{2}^{2} \cdot \frac{1}{R_{S}} \cdot F_{H}$ & $\begin{array}{l}\text { Kievert } \\
(1997)\end{array}$ \\
\hline 7 & $\begin{array}{l}\text { Fluks massa } \\
\text { Mass flux }\end{array}$ & $F_{H}=J_{w i} \cdot R_{S}$ & $\begin{array}{l}\text { Kievert } \\
(1997)\end{array}$ \\
\hline 8 & $\begin{array}{l}\text { Lapisan kulit partikel } \\
\text { Skin layer particle }\end{array}$ & $R_{s}=\frac{R_{2}-R_{1}}{1-x \cdot d_{s} / d_{w}}$ & $\begin{array}{l}\text { Kievert } \\
(1997)\end{array}$ \\
\hline
\end{tabular}

9 Difusi untuk particle

9 berbentuk bola

(Gambar 3)

Disffusion of

spherical particles

(Figure 3)

$$
\begin{aligned}
\frac{d \rho_{W}}{d t}=-\frac{1}{r^{2}} \frac{d}{d r}\left[-r^{2} \cdot D_{W} \cdot \frac{d \rho_{W}}{d r}\right] & \frac{\partial \rho_{W}}{\partial r}=0 \\
j_{W i}= & -\frac{D_{W}}{1-\rho_{W} / d_{W}} \cdot \frac{\partial \rho_{W}}{\partial r} \\
= & \frac{S h D_{d i f f}}{D} \cdot \rho_{g} \cdot \operatorname{Ln} \frac{1-\omega_{i}}{1-\omega_{g}}
\end{aligned}
$$

\begin{tabular}{lll}
\hline Koordinat $z$ \\
$z$ coordinate
\end{tabular}$\quad z=\int_{R 1}^{r} \rho s \cdot r^{2} d \gamma \quad$ Kievert


Tabel 2. Lanjutan

Table 2. Continues

\begin{tabular}{|c|c|c|c|c|}
\hline No. & $\begin{array}{l}\text { Pengamatan } \\
\text { Observations }\end{array}$ & & $\begin{array}{l}\text { Persamaan } \\
\text { Equations }\end{array}$ & $\begin{array}{l}\text { Referensi } \\
\text { References }\end{array}$ \\
\hline 11 & $\begin{array}{l}\text { Disfusi untuk particle } \\
\text { berbentuk bola dengan } \\
\text { koordinat } z \\
\text { Diffusion of spherical } \\
\text { particles with } z \\
\text { cordinate }\end{array}$ & $\begin{array}{l}t=0 \\
t>0 \\
t>0\end{array}$ & 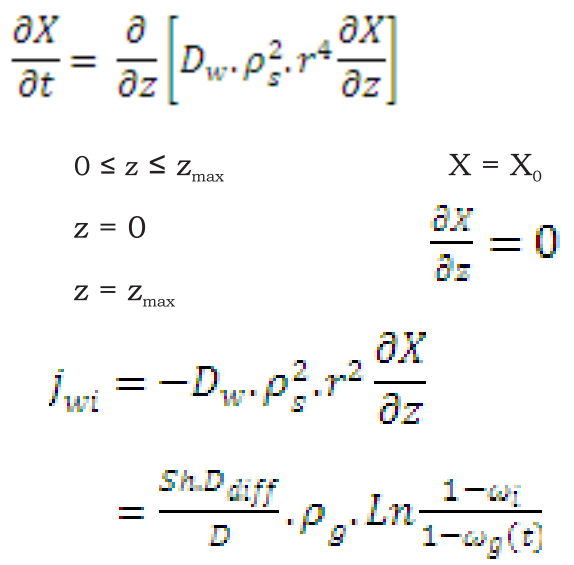 & \\
\hline
\end{tabular}

\begin{tabular}{|c|c|c|c|}
\hline 12 & $\begin{array}{l}\text { Laju perpindahan } \\
\text { partikel } \\
\text { Flow rate of gas- } \\
\text { particles mas } \\
\text { transfer }\end{array}$ & $\frac{d m}{d t}=k_{g} \cdot A \cdot\left(H_{w}-H_{a}\right)$ & $\begin{array}{l}\text { Huang dan } \\
\text { Mujumdar } \\
\quad(2007)\end{array}$ \\
\hline 13 & $\begin{array}{l}\text { Diameter partikel } \\
\text { Particle diameter }\end{array}$ & $d_{p}^{1}=\frac{1}{1+K} d_{\text {part }}+\frac{K}{K+1} \sqrt[3]{d_{\text {part }}^{3}+d_{v i r t}^{3}}$ & $\begin{array}{l}\text { Zbicinski } \\
\text { dan Zietara } \\
\text { (2004) }\end{array}$ \\
\hline 14 & $\begin{array}{l}\text { Definisi } \mathrm{K} \\
K \text { definition }\end{array}$ & $K=\frac{m_{A g g} \cdot d_{\text {part }}^{3} \rho_{p}}{m_{A g g}\left(d_{p}^{3} \cdot \rho_{s}+d_{v i r t}^{3} \cdot \rho_{v i r t}\right)}$ & $\begin{array}{l}\text { Zbicinski } \\
\text { dan Zietara } \\
\quad(2004)\end{array}$ \\
\hline 15 & $\begin{array}{l}\text { Waktu lintasan } \\
\text { Trajectory time }\end{array}$ & $\begin{array}{c}\theta_{t}=\left(\frac{64}{\pi}\right)^{2 / 3} \frac{V^{2 / 3}}{6.4 U_{A} d_{o}^{\prime}} \\
d_{o}^{\prime}=d_{o}\left(\rho_{s} / \rho_{g}\right)^{1 / 2}\end{array}$ & $\begin{array}{l}\text { Schweitzer } \\
\text { (1979) }\end{array}$ \\
\hline 16 & $\begin{array}{l}\text { Perubahan suhu } \\
\text { Temperature } \\
\text { change }\end{array}$ & $\frac{d T}{d t}=\pi \cdot D \cdot \frac{\lambda \cdot N u \cdot\left(T_{g}-T a m b\right)-D \cdot j_{w i} \cdot \Delta H_{v a v}}{m_{s} \cdot\left(C_{p, s}+X \cdot C_{p, w}\right)}$ & $\begin{array}{l}\text { Kievert } \\
(1997)\end{array}$ \\
\hline 17 & \multicolumn{2}{|l|}{$\begin{array}{l}\text { Laju perpindahan } \\
\text { energi } \\
\text { Energy transfer } \\
\text { flow rate }\end{array}$} & $\begin{array}{l}\text { Kievert } \\
(1997)\end{array}$ \\
\hline $\begin{array}{l}\text { dima } \\
\text { wher }\end{array}$ & $\begin{array}{ll}\text { rana: } & =\text { diam } \\
\text { Sh } & =\text { nilai } \\
\mathrm{D}_{\text {diff }} & =\text { koefi } \\
\rho_{\mathrm{g}} & =\text { dens } \\
\dot{\omega}_{\mathrm{i}} \text { dan } \dot{\omega}_{\mathrm{g}} & =\text { fraks } \\
& \text { partil }\end{array}$ & \multicolumn{2}{|c|}{$\begin{aligned}= & \text { diameter partikel }(\mathrm{m}) \text { (particle diameter) } \\
= & \text { nilai bilangan sherwood tidak berdimensi (number value of sherwood with no dimention) } \\
= & \text { koefisien difusi uap pada fase gas }\left(\mathrm{m}^{2} / \mathrm{s}\right) \text { (coeficient of vapor diffusion on gas phase) } \\
= & \text { densitas udara }\left(\mathrm{kg} / \mathrm{m}^{2}\right) \text { (air density) } \\
\mathrm{g}_{\mathrm{g}}= & \text { fraksi massa uap dalam udara di antarmuka partikel dan fraksi massa uap di udara sekitar } \\
& \text { partikel (vapor mass fraction on the particle surface and in the air around the particle) }\end{aligned}$} \\
\hline
\end{tabular}




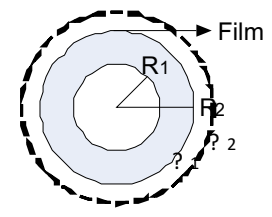

Gambar 3. Partikel tetesan umpan

Figure 3. Feed droplet particle

partikel $(\mathrm{m} / \mathrm{s}) ; \mathrm{d}_{\mathrm{w}}$ adalah densitas spesifik air $\left(\mathrm{kg} / \mathrm{m}^{3}\right) ; \mathrm{D}$ adalah diameter partikel $(\mathrm{m}) ; \rho_{\mathrm{s}}$ adalah densitas padatan $\left(\mathrm{kg} / \mathrm{m}^{3}\right) ; z$ adalah koordinat ruang pusat padatan $(\mathrm{kg})$; $\mathrm{k}_{\mathrm{g}}$ adalah koefisien perpindahan massa $\left(\mathrm{kg} / \mathrm{m}^{2} . \mathrm{s}\right) ; \mathrm{H}_{\mathrm{w}}$ dan $\mathrm{H}_{\mathrm{a}}$ adalah kelembaban pada permukaan tetesan dan medium pengering $(\mathrm{kg} / \mathrm{kg}) ; \mathrm{d}_{\text {part }}$ adalah diameter partikel awal $(\mathrm{m}) ; \mathrm{d}_{\text {virt }}$ adalah diameter partikel secara virtual $(\mathrm{m}) ; \mathrm{m}_{\mathrm{Agg}}$ adalah massa aglomerasi $(\mathrm{kg}) ; \rho_{\mathrm{p}}$ adalah densitas tetesan partikel $\left(\mathrm{kg} / \mathrm{m}^{3}\right) ; \rho_{\text {virt }}$ adalah densitas partikel secara virtual $\left(\mathrm{kg} / \mathrm{m}^{3}\right)$.

Simbol V menyatakan volume ruang pengering $\left(\mathrm{m}^{3}\right) ; \mathrm{U}_{\mathrm{A}}$ adalah kecepatan ke arah aksial $(\mathrm{m} / \mathrm{s}) ; \mathrm{d}_{\mathrm{o}}$ adalah diameter lubang nosel $(\mathrm{m}) ; \mathrm{T}_{\mathrm{g}}$ dan $\mathrm{T}_{\text {amb }}$ adalah suhu udara pengering dan suhu ambient (K); $\lambda$ adalah konduktivitas panas pada fase gas $(\mathrm{J} / \mathrm{s} . \mathrm{m} . \mathrm{K}) ; \mathrm{m}_{\mathrm{s}}$ adalah massa partikel padatan (kg); $\mathrm{C}_{\mathrm{p}, \mathrm{s}}$ dan $\mathrm{C}_{\mathrm{p}, \mathrm{w}}$ adalah panas spesifik padatan dan panas spesifik air (J/kg.K) serta $Q$ adalah laju perpindahan panas dari dapat fluks panas $(\mathrm{J} / \mathrm{m} . \mathrm{s})$ dan $\mathrm{T}_{\mathrm{p}}$ adalah suhu tetesan partikel (K). Saleh (2010) menyatakan bahwa sebuah fenomena yang sangat penting dari pengoperasian pengering semprot adalah deposisi partikel di dinding yang dipengaruhi oleh pola suhu dan kelembaban di dalam pengering ketika partikel lembab kontak dengan dinding ruang pengering semprot.

\section{HASIL DAN PEMBAHASAN}

Dari simulasi yang dilakukan dapat diprediksi kecepatan partikel (tetesan) dan kecepatan aliran udara kering di dalam ruang pengering. Kecepatan partikel mulai diamati sejak tetesan lateks keluar dari lubang nosel sampai partikel kering sebelum menyentuh dinding ruang pengering, sedangkan kecepatan udara mulai diamati sejak masuk ke dalam ruang pengering sampai ke pipa keluaran pada bagian bawah. Profil kecepatan partikel pada berbagai kadar air lateks dan suhu udara pengeringan dapat dilihat pada Gambar 4, sedangkan profil kecepatan udara pengering disajikan pada Gambar 5.

Profil kecepatan partikel selama simulasi proses pengeringan tidak terlalu berbeda (Gambar 4). Kecepatan awal tetesan partikel saat keluar lubang nosel (posisi 0 $\mathrm{mm}$ ) yaitu $17,82 \mathrm{~m} / \mathrm{s}$. Kesamaan ini terjadi karena laju alir lateks dan nosel yang digunakan pada berbagai variasi ditetapkan sama yaitu $6 \times 10^{-5} \mathrm{~m}^{3} / \mathrm{s}$. Schweitzer (1979) menyatakan bahwa kecepatan partikel ditentukan oleh laju alir dan diameter lubang nosel. Diameter ini berkaitan dengan luas penampang lubang nosel yang dilalui lateks dan akan menentukan ukuran diameter tetesan. Pada simulasi ini, diameter tetesan akan langsung terhitung dari data nosel yang dimasukkan ke dalam simulasi dengan persamaan dasar perpindahan massa seperti persamaan (1).

Laju tetesan lateks mengalami peningkatan setelah terjadi kontak dengan udara pengering. Besaran peningkatan dari kecepatan partikel sangat ditentukan oleh kecepatan udara pengering. Semakin cepat udara pengeringan maka semakin cepat laju partikel. Pada jarak sekitar 300-350 mm dari nosel, kecepatan partikel terus mengalami penurunan sampai menyentuh dinding ruang pengering. Penurunan ini terjadi karena kecepatan udara mengalami penurunan yang diakibatkan terakumulasinya uap air pada udara pengering (udara menjadi basah). Kecepatan akhir partikel kering sesaat sebelum menyentuh dinding ruang pengering bervariasi sekitar $5-8 \mathrm{~m} / \mathrm{s}$.

Berbeda dengan partikel, kecepatan awal udara pengering tidak sama antara satu dengan yang lainnya (Gambar 5). Hasil simulasi menunjukkan bahwa kecepatan awal udara sangat dipengaruhi oleh suhu. Peningkatan suhu udara pengering, juga akan meningkatkan kecepatannya. Perubahan suhu udara pengering kaitannya dengan perubahan densitasnya. Semakin tinggi suhunya, maka semakin kering udara dan semakin kecil densitasnya. Dengan laju alir massa yang tetap sebesar $1 \mathrm{~kg} / \mathrm{s}$ dan luas penampang yang sama, semakin kecil densitas udara maka semakin besar kecepatan udara. 


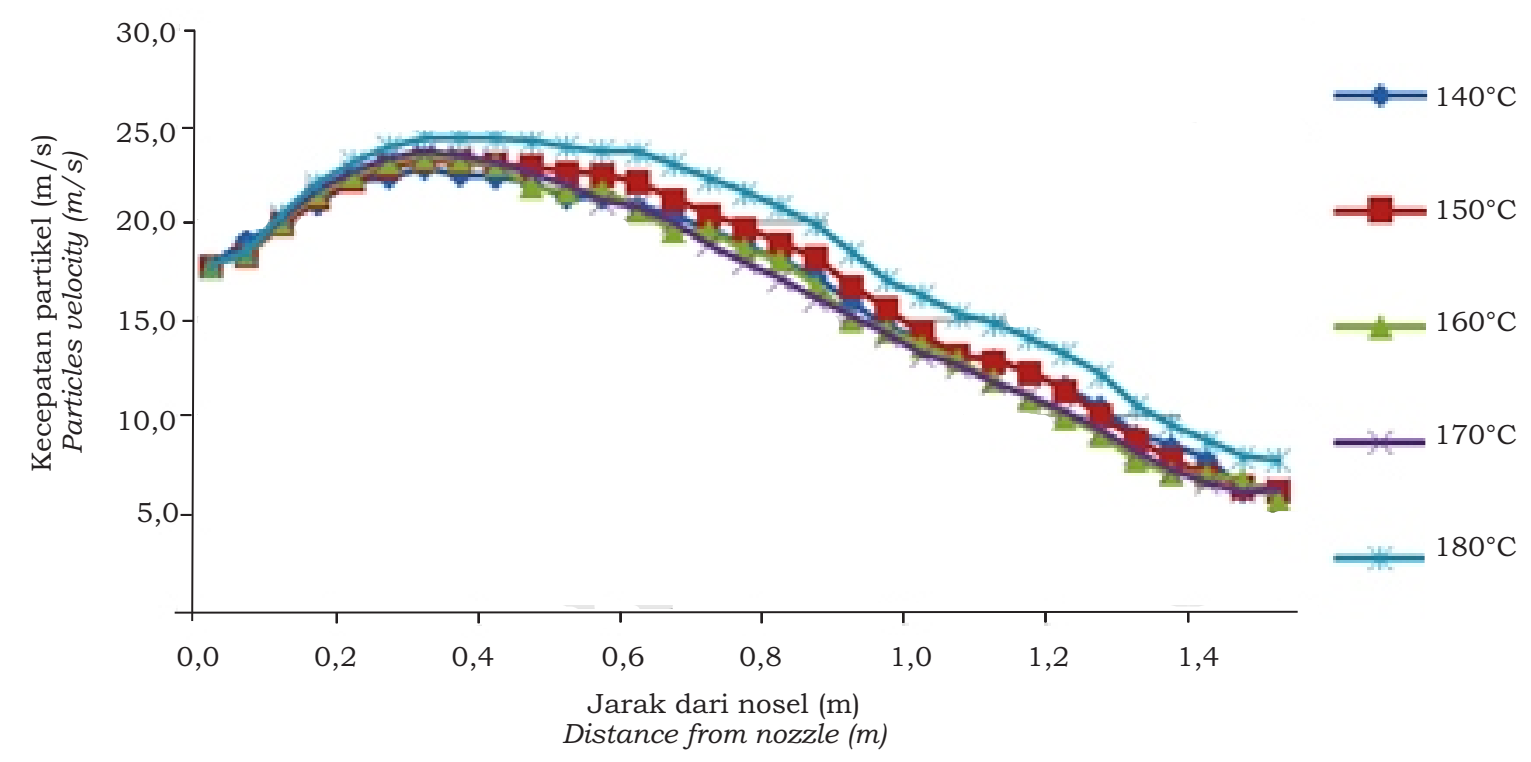

Gambar 4. Profil kecepatan tetesan partikel lateks pada berbagai suhu udara pengering dan kadar air lateks

Figure 4. Velocity profile of latex particle droplets at various drying air temperatures and latex water contents

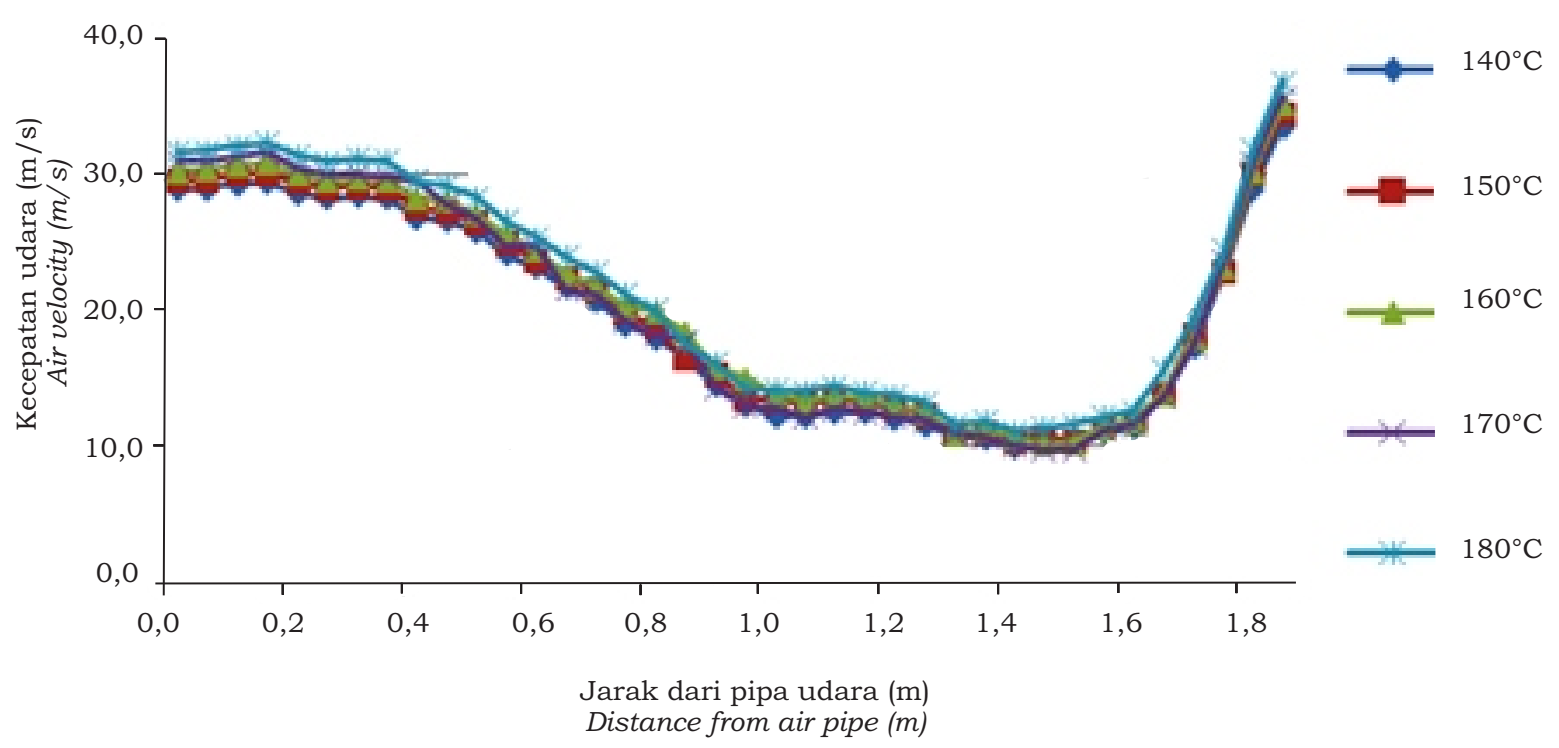

Gambar 5. Profil kecepatan udara pengering di sepanjang ruang pengering pada berbagai suhu udara dan kadar air lateks

Figure 5. Velocity profile of drying air along the drying chamber at various drying air temperatures and latex water contents 
Seperti terlihat pada Gambar 4, kecepatan awal udara kering berdasarkan suhunya yaitu $28,81 \mathrm{~m} / \mathrm{s}$ untuk udara bersuhu $140{ }^{\circ} \mathrm{C} ; 29,51 \mathrm{~m} / \mathrm{s}$ (udara $150^{\circ} \mathrm{C}$ ); $30,20 \mathrm{~m} / \mathrm{s}$ (udara $160^{\circ} \mathrm{C}$ ); $30,90 \mathrm{~m} / \mathrm{s}$ (udara $170^{\circ} \mathrm{C}$ ) dan $31,60 \mathrm{~m} / \mathrm{s}$ untuk suhu udara $180^{\circ} \mathrm{C}$. Kecepatan ini cenderung meningkat sebelum udara kering kontak dengan tetesan lateks. Peningkatan kecepatan ini terjadi sampai jarak $100 \mathrm{~mm}$ dari pipa udara pengering. Setelah jarak ini, kecepatan udara cenderung mengalami penurunan. Turunnya kecepatan udara ini disebabkan oleh uap air yang mulai terakumulasi di udara kering akibat dari proses penguapan pelarut yang terdapat di tetesan lateks dan partikel karet yang ada di udara.

Kecepatan udara ini akan kembali naik setelah partikel menyentuh dinding ruang pengering persisnya pada jarak sekitar 1500 mm dari pipa udara. Kenaikan kecepatan ini juga disebabkan perubahan luas penampang yang dilalui udara. Pada bagian bawah ruang pengering yang berbentuk kerucut diameternya mengecil ke bawah (Gambar 2). Dengan laju alir massa yang sama, perubahan diameter ruang pengering yang mengecil akan meningkatkan kecepatan udara keluar ruang pengering. Kecepatan merupakan fungsi dari laju alir volumetrik dan luas penampang yang akan dilalui (Schweitzer, 1979). Kecepatan udara ketika keluar dari ruang pengering sekitar $33-38 \mathrm{~m} / \mathrm{s}$ tergantung dari kadar air lateks dan suhu udara pengering.

\section{Pengeringan Lateks Karet Alam}

Proses pengeringan yang terjadi pada lateks karet alam dapat dilihat dari perubahan kadar airnya. Persamaan yang menggambarkan proses ini adalah persamaan difusi yang berkaitan dengan konsentrasi air seperti persamaan diferensial (9) dan (11). Lateks karet alam dapat dikatakan kering apabila kadar pelarut air di dalam lateks berkurang akibat proses penguapan. Profil perubahan kadar air lateks karet alam pada berbagai suhu udara pengering yang diperoleh disajikan pada Gambar 6.

Berdasarkan Gambar 6, kadar air lateks karet alam mengalami penurunan selama proses pengeringan pada berbagai suhu udara pengering. Hal ini menunjukkan bahwa telah terjadi proses pengeringan atau penguapan air yang ada di dalam lateks. Kadar air pada produk lateks kering dipengaruhi oleh kadar air awal. Lateks dengan kadar air 80\% diprediksi akan menghasilkan produk lateks kering dengan kadar air sekitar 0,44-0,56\%, lateks berkadar air 75\% menghasilkan kadar air sekitar 0,40-0,58\%, lateks berkadar air $70 \%$ kadar air produknya sekitar 0,350,48\%, dan lateks dengan kadar air 65\% akan menghasilkan produk berkadar air sebesar 0,32-0,34\%.

Air yang menguap dari tetesan lateks ini diidentifikasi sebagai air bebas. Air bebas mudah hilang apabila terjadi penguapan atau pengeringan dan dapat digunakan oleh mikroorganisme untuk pertumbuhan. Oleh karena itu dengan hilangnya air bebas pada partikel karet, maka tidak terjadi pertumbuhan mikroorganisme sehingga tepung karet alam menjadi lebih tahan lama. Air bebas ini juga memberikan tekanan uap penuh dan terutama terdapat di dalam rongga-rongga partikel padat tersebut (McCabe et al.,1993).

Meski diprediksi menghasilkan produk dengan kadar air bervariasi, produk yang dihasilkan sudah dapat dikategorikan karet kering. Kadar air dari karet kering sekitar 0,3 - 1,0\% (Setiamidjaja, 1993). Selain kadar air lateks, dari Gambar 4 juga dapat dilihat waktu pengeringan untuk setiap variasi pengering. Hasil simulasi CFD menunjukkan bahwa waktu pengeringan lateks karet alam dengan berbagai kadar air dipengaruhi suhu udara pengering yang digunakan. Semakin tinggi suhu udara pengering, maka semakin cepat proses pengeringan. Waktu pengeringan tercepat sebesar 0,087 detik secara umum dihasilkan pada proses pengeringan menggunakan udara kering bersuhu $180^{\circ} \mathrm{C}$. Sedangkan waktu pengeringan terlama 0,112 detik dihasilkan dari udara kering dengan suhu $140^{\circ} \mathrm{C}$.

Dengan waktu sekitar 0,087 - 0,112 detik, lateks karet alam sudah kering sebelum menyentuh dinding ruang pengering. Hal ini terjadi karena waktu pengeringan lebih cepat dibandingkan waktu lintasan lateks di ruang pengering. Berdasarkan persamaan (15), untuk waktu 


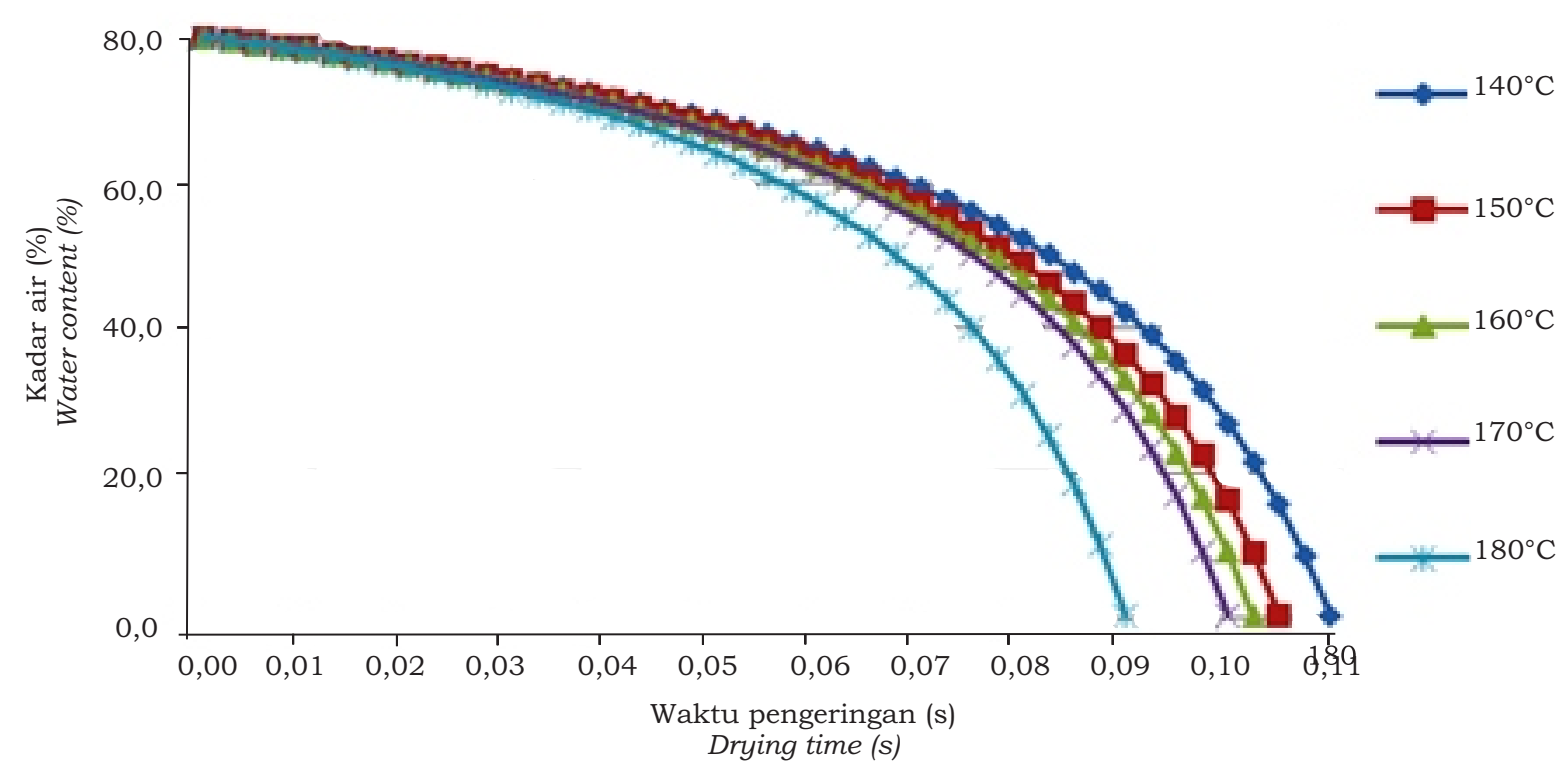

Gambar 6. Profil kadar air tetesan lateks pada berbagai suhu udara pengering dan kadar air lateks

Figure 6. Water content profile of latex droplets at various drying air temperatures and latex water contents

lintasan lateks selama berada di ruang pengering terutama bagian berbentuk silinder sekitar 1,72-1,80 detik. Profil waktu lintasan lateks pada berbagai suhu udara pengering dapat dilihat pada Gambar 7 .
Gambar 7 memperlihatkan bahwa waktu lintasan lateks di dalam ruang pengering juga dipengaruhi suhu udara pengering sama seperti waktu pengeringan. Semakin tinggi suhu udara pengering, maka semakin cepat waktu yang dibutuhkan lateks di dalam ruang pengering.

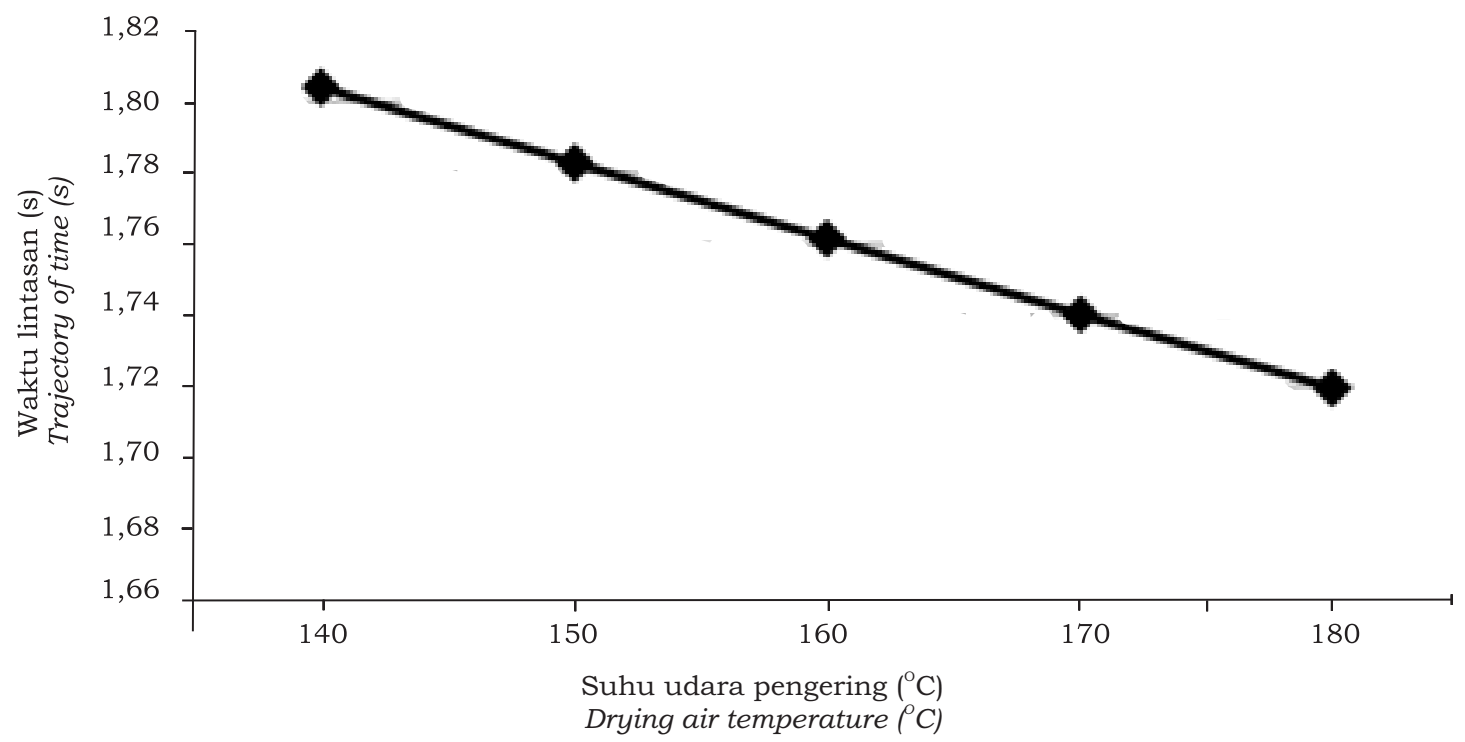

Gambar 7. Waktu lintasan lateks di ruang pengering berbentuk silinder Figure 7. Trajectory time of latex in cylindrical drying chamber 


\section{Prediksi Diameter Partikel di Ruang Pengering}

Gambar 8 menunjukkan profil prediksi diameter partikel lateks karet alam di dalam ruang pengering. Dari Gambar 8 diketahui bahwa diameter tetesan yang disemprotkan nosel dipengaruhi oleh kadar air yang terdapat di lateks karet alam. Hasil simulasi memprediksi bahwa diameter awal tetesan yang keluar dari nosel hampir sama yaitu sekitar 130 - $135 \mu \mathrm{m}$ (mikron). Filkova dan Mujumdar (1995) menyatakan bahwa kisaran dari ukuran tetesan dan partikel yang dihasilkan oleh nosel bertekanan adalah sekitar 10 - $800 \mu \mathrm{m}$. Persamaan untuk menghitung diameter partikel salah satunya tercantum dalam model yang dikembangkan Zbicinski dan Zietara (2004) yaitu persamaan (14).

Selama proses pengeringan, tetesan akan mengalami perubahan ukuran menjadi lebih kecil atau penyusutan (shrinkage). Besaran penyusutan dan prediksi diameter akhir dari partikel produk kering dipengaruhi oleh kadar air awal lateks yang akan dikeringkan dan suhu udara kering yang digunakan. Semakin rendah kadar air lateks dan semakin tinggi suhu udara kering, maka semakin kecil diameter produk akhir yang dihasilkan (Gambar 7).

Prediksi diameter akhir produk lateks kering yang terbesar $(134,54 \mu \mathrm{m})$ diperoleh dari proses pengeringan lateks dengan kadar air $80 \%$ menggunakan udara kering bersuhu $140^{\circ} \mathrm{C}$. Sedangkan diameter terkecil $(130,5$ $\mu \mathrm{m})$ dihasilkan dari kombinasi pengeringan untuk lateks berkadar air 65\% yang dikeringkan dengan udara bersuhu $180^{\circ} \mathrm{C}$. Untuk pengeringan semprot dengan nosel bertekanan, ukuran rata-rata produk kering yang dihasilkan bervariasi antara 50-250 $\mu \mathrm{m}$ (Genskow dkk, 2008).

Penyusutan ini terjadi karena proses penguapan air bebas baik yang terdapat di permukaan maupun di dalam partikel. Apabila pelarut yang terdapat di tetesan dikeluarkan dari partikel basah, bahan itu akan menyusut. Karena ukuran partikelpartikel karet yang sangat kecil (dalam ukuran mikrometer), penyusutan ini tidak menjadi masalah (McCabe et al., 1993).

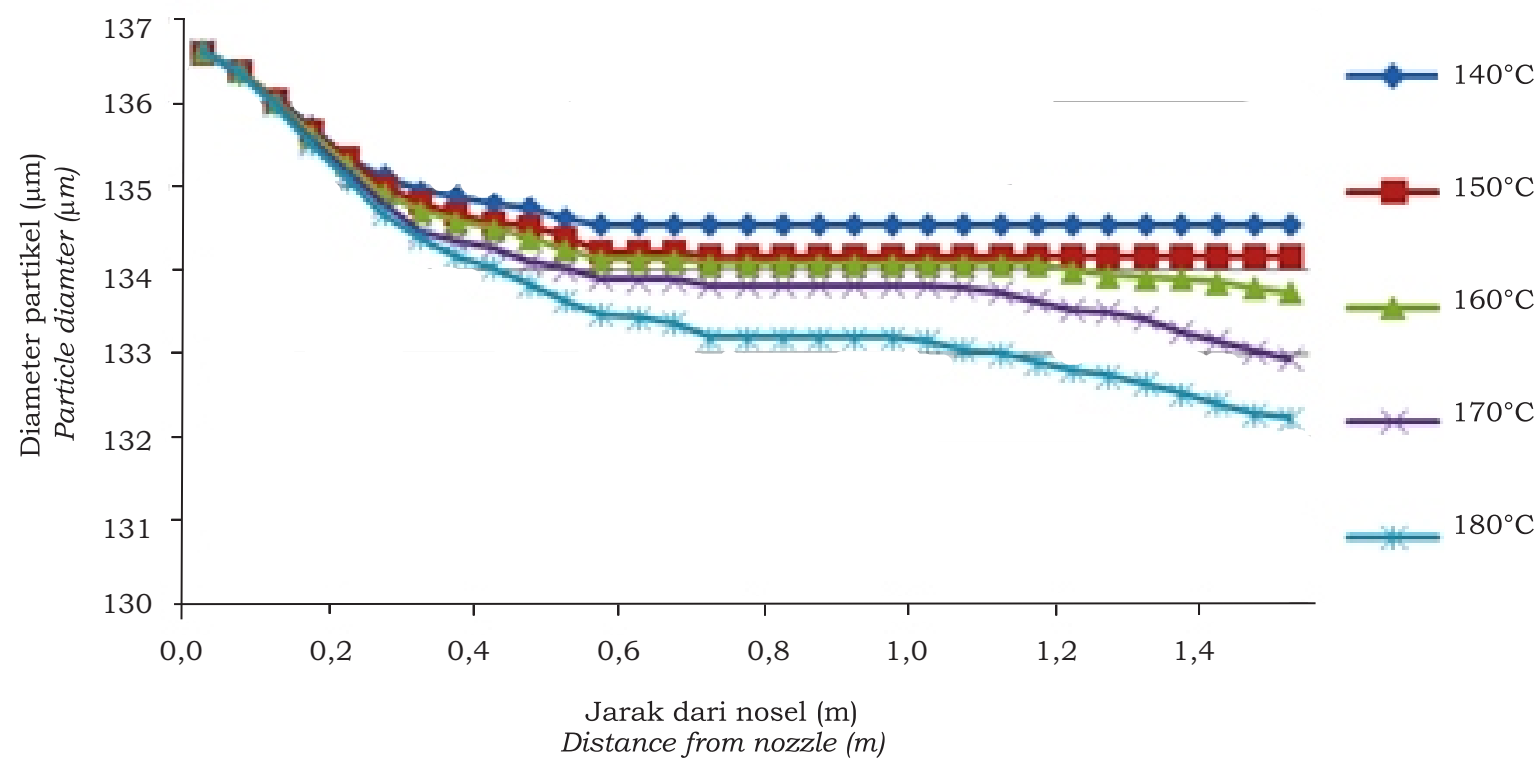

Gambar 8. Prediksi diameter partikel tepung lateks di ruang pengering pada berbagai suhu udara pengering dan kadar air lateks

Figure 8. Diameter prediction of latex powder particle in the drying chamber at various drying air temperatures and latex water contents 
Perubahan Suhu Partikel dan Suhu Udara Pengering

Simulasi pengering semprot ini juga dapat memprediksi perubahan suhu partikel karet alam dan suhu udara pengering. Persamaan dasar yang dapat menggambarkan perubahan suhu dalam sistem pengeringan semprot adalah perpindahan panas, seperti persamaan (17). Prediksi suhu partikel hasil simulasi CFD pada berbagai perlakuan selama proses pengeringan berlangsung dapat dilihat pada Gambar 9. Sedangkan profil perubahan suhu udara pengering ditampilkan pada Gambar 10.

Hasil simulasi menunjukkan bahwa suhu partikel karet alam mengalami peningkatan dibandingkan dengan suhu awal saat masuk ke dalam ruang pengering. Suhu awal lateks yang masuk ditetapkan suhu ruang $\left(27^{\circ} \mathrm{C}\right)$. Suhu akhir produk karet kering bervariasi tergantung dari kadar air lateks dan suhu udara pengering. Semakin rendah kadar air dan semakin besar suhu udara pengering, maka semakin tinggi suhu keluaran partikel karet alam. Suhu keluaran partikel tertinggi $\left(53,51^{\circ} \mathrm{C}\right)$ diperoleh dari proses pengeringan lateks berkadar air $65 \%$ yang dikeringkan menggunakan udara kering bersuhu $180^{\circ} \mathrm{C}$. Sedangkan suhu terendah $\left(37,44^{\circ} \mathrm{C}\right)$ didapat dari pengeringan lateks dengan kadar air $80 \%$ pada suhu udara pengering $140^{\circ} \mathrm{C}$.

Peningkatan suhu partikel karet alam ini terjadi karena proses perpindahan energi/panas dari udara pengering ke partikel karet alam. Perpindahan panas ini menyebabkan peningkatan suhu tetesan lateks sehingga proses penguapan terjadi. Untuk pengering semprot bertipe aliran searah, suhu produk akhir lebih rendah dari pada suhu udara masuk (Filkova dan Mujumdar, 1995). Suhu udara pengering menentukan kecepatan perpindahan panas/energi ke tetesan. Dengan demikian, peningkatan suhu udara pengering akan meningkatan jumlah panas yang dipindahkan dari udara ke tetesan (Shabde, 2006). Oleh karena itu, suhu partikel akan meningkat seiring meningkatnya suhu udara kering yang digunakan.

Pada Gambar 8 terlihat penurunan suhu partikel terutama untuk udara pengering $140^{\circ} \mathrm{C}, 150^{\circ} \mathrm{C}$, dan $160^{\circ} \mathrm{C}$. Hal ini terjadi karena adanya udara balik yang kembali ke atas setelah memasuki bagian kerucut. Udara ini memiliki suhu yang lebih rendah dibanding suhu awal udara karena

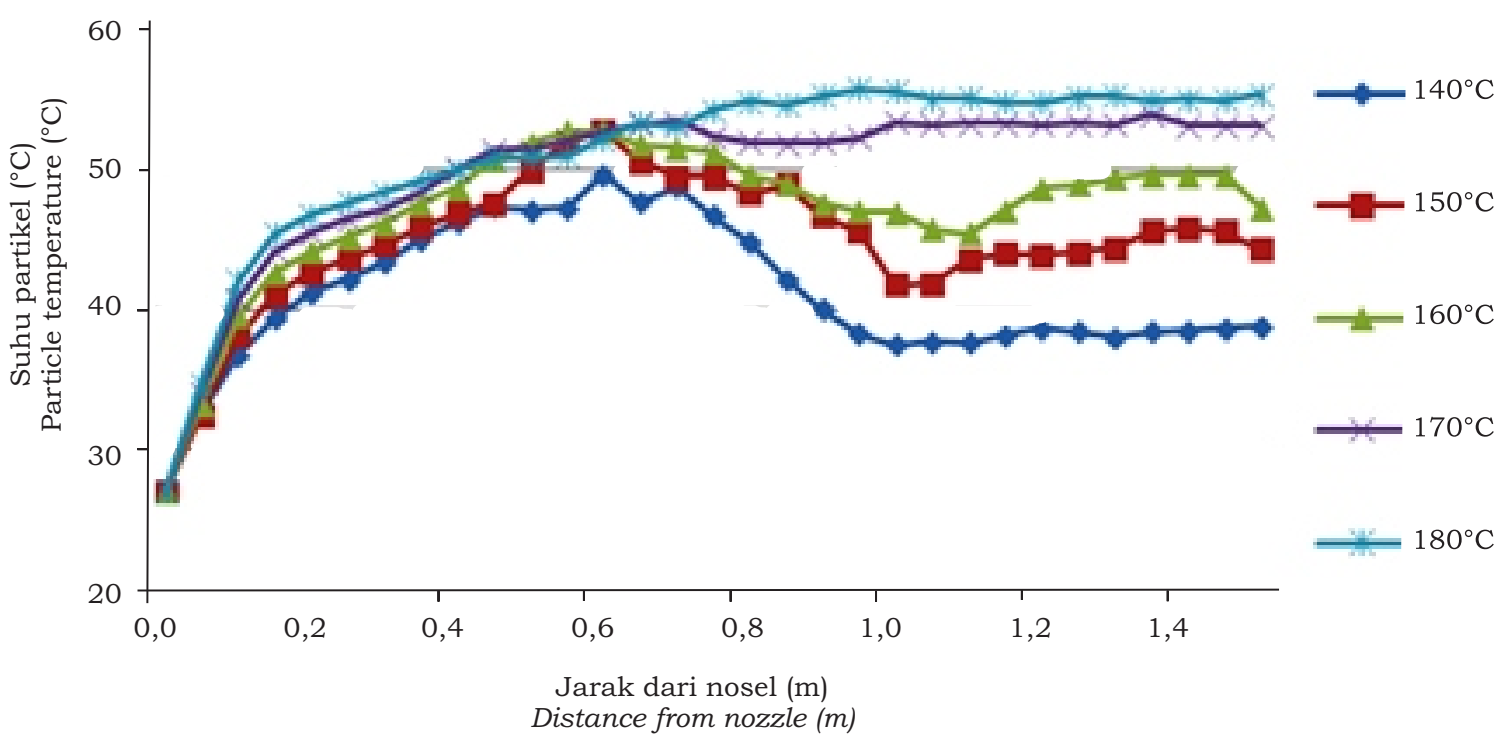

Gambar 9. Prediksi profil suhu partikel tepung lateks pada berbagai suhu udara pengering dan kadar air lateks

Figure 9. Prediction profile of latex powder particle at various drying air temperatures and latex water contents 


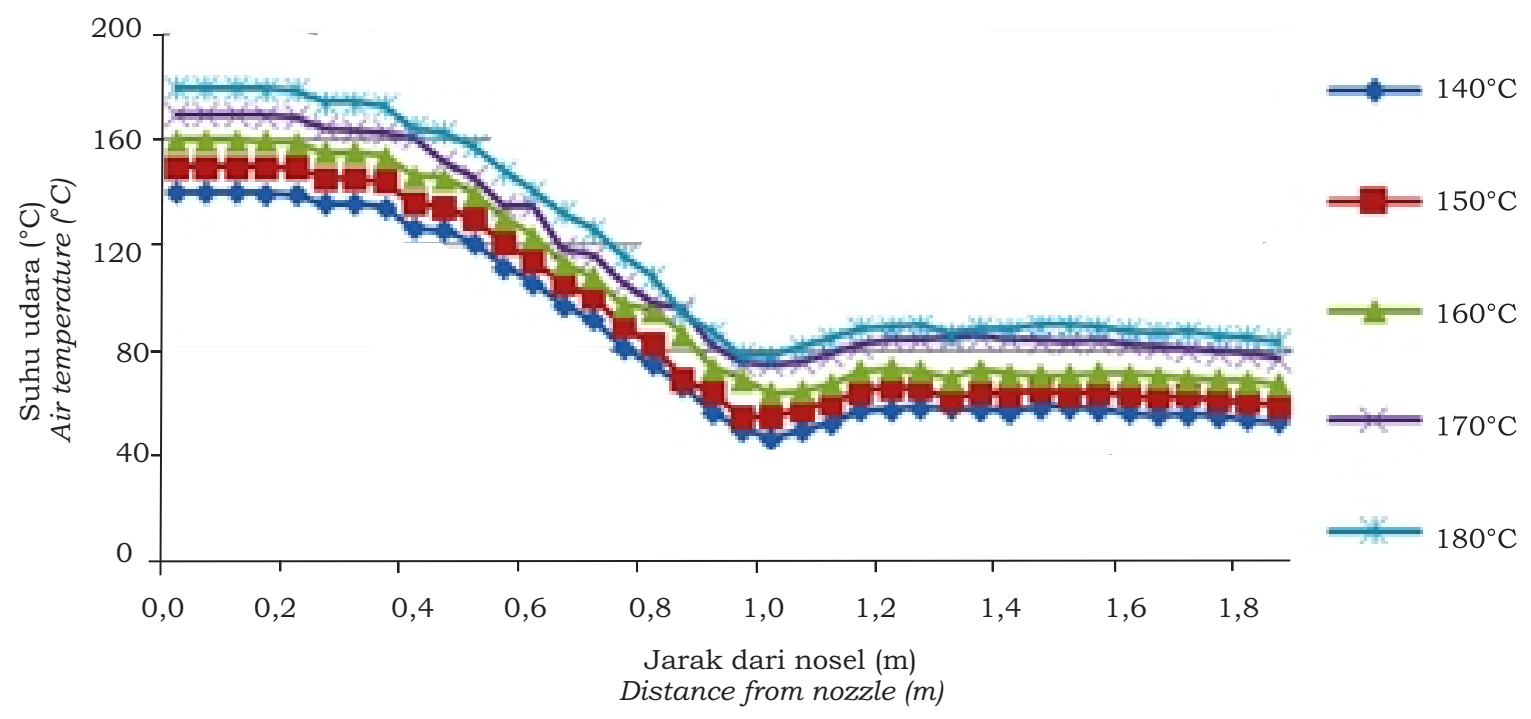

Gambar 10. Prediksi profil suhu udara pengering pada berbagai kadar air lateks Figure 10. Prediction profile of drying air temperatures at various latex water contents

adanya kandungan uap air yang terakumulasi di udara akibat proses pengeringan lateks. McCabe et al. (1993) menyatakan bahwa perubahan suhu di dalam ruang pengering bergantung pada sifat bahan lateks dan kandungan zat cairnya, suhu udara pengering, waktu pengeringan serta suhu akhir yang diperbolehkan dalam pengeringan partikel padat.

Sama seperti partikel, suhu udara pengering cenderung menurun sejak keluar dari pipa udara pengering. Besaran penurunan suhu udara pengering dipengaruhi oleh kadar air lateks (Gambar 10). Semakin tinggi kadar air lateks, maka semakin rendah suhu udara keluaran. Penurunan suhu ini terjadi sampai jarak 1000 mm (1 meter) dari pipa udara. Setelah posisi ini, suhu udara cenderung konstan walaupun ada yang mengalami sedikit peningkatan.

Turunnya suhu udara pengering ini secara umum terjadi karena perpindahan energi/panas dari udara ke tetesan/ partikel. Untuk suhu udara paling rendah yang terlihat pada jarak 1000 meter dari pipa udara terjadi karena adanya udara balik yang memiliki suhu lebih rendah dari udara di atasnya. Hal ini juga bisa dilihat dari profil suhu partikel dimana pada posisi ini juga merupakan suhu terendah. Kievert (1997) menyatakan bahwa perubahan suhu udara tergantung pada kelembaban dan suhu di sekitar partikel.

\section{KESIMPULAN DAN SARAN}

Dari penelitian simulasi yang sudah dilakukan dapat disimpulkan bahwa kadar air lateks dan suhu udara pengering berpengaruh terhadap proses pengeringan yang ditentukan oleh kecepatan udarapartikel, waktu pengeringan, diameter partikel, kadar air produk, dan perubahan suhu udara-partikel. Hasil simulasi memprediksi diameter partikel produk akhir sekitar 130-135 mikrometer dengan kadar air sekitar 0,32-0,58\%. Suhu produk akhir yang keluar dari ruang pengering sekitar 37$54{ }^{\circ} \mathrm{C}$. Penelitian lanjutan perlu dilakukan untuk validasi hasil simulasi dengan kondisi nyata pada praktek pengeringan semprot lateks. 


\section{DAFTAR PUSTAKA}

Abidin, A.Z and A. Vachlepi. 2011. Natural rubber powder production from latex : process and equipment design (spray dryer chamber) for latex drying. international seminar on chemical engineering. Soehadi Reksowardojo 2011. Institut Teknologi Bandung. 5-7 Oktober 2011. Bandung. pp MST-05.

Bird, B.B., W.E. Stewart and E.N. Lightfoot. 2002. Transport Phenomena. Second Edition. Wiley and Sons, Inc, USA.

Direktorat Jenderal Perkebunan. 2011. Statistik Perkebunan Indonesia 20102012. Kementerian Pertanian, Jakarta.

Filkova, I and A.S. Mujumdar. 1995. Industrial Spray Drying Systems. Handbook of Industrial Drying $2^{\text {th }}$ Edition. Volume 1. CRC Press, Singapore.

Genskow, L.R., W.E. Beimesch, J.P. Hecht, I.C. Kemp, T. Langrish, T. Schwartzbach, and L. Smith. 2008. Psychrometry, Evaporative Cooling, and Solid Drying. Perry's Chemical Engineers' Handbook $8^{\text {th }}$ Edition. Section 12. The McGraw-Hill Companies, Inc, New York.

Huang, L. X. and A. S. Mujumdar. 2007. A computational fluid dynamic study of a low humidity co-current spray dryer. Asia-Pacific Journal of Chemical Engineering Vol 2 Issue 1. 12-19.
Kievert, F. G. 1997. Modelling Quality in Spray Drying. Proefschrift-Technische Universiteit Eindhoven. ISBN 90-3861008-4.

McCabe, W. L., J. C. Smith., and P. Harriott. 1993. Unit Operations of Chemical Engineering. McGraw-Hill Chemical Engineering Series, Singapore.

Saleh, Saad Nahi. 2010. CFD Simulations of a Co-current Spray Dryer. World Academy of Science, Engineering and Technology. International Journal Issue 38. 772-777 www.waset.org diakses pada tanggal 18 November 2011.

Setiamidjaja, D. 1993. Karet. Budidaya dan Pengolahan. Kanisius. Yogyakarta.

Schweitzer, P. A. 1979. Handbook of Separation Techniques for Chemical Engineers. McGraw-Hill, Inc. New York, USA.

Shabde, V. 2006. Optimal Design and Control of A Spray Drying Process That Manufactures Hollow Micro-Particles. A Dissertation in Chemical Engineering. Texas Tech University. Texas, USA.

Zbicinski, I., and R. Zietara. 2004. CFD model of counter current spray drying process. Proc. $14^{\text {th }}$ International Drying Symposium (IDS). Sao Paulo, Brazil 2225 August. Vol.A. 169-176. 